\title{
Community Based Study of Abortion Complications And Care Sought by Rural Tribal Women Of Extremely Low Resource Settings.
}

\author{
Shakuntala Chhabra ${ }^{1}$ and AKANKSHA SUMAN ${ }^{1}$ \\ ${ }^{1}$ Mahatma Gandhi Institute of Medical Sciences
}

May 6, 2020

\begin{abstract}
ABSTRACT BACKGROUND Knowingcomplication, care sought is essential for understanding risks, services, program, policies for abortion care. MATERIAL METHODS Rural community based study was carried out in villages near Sewagram Wardha and Melghat, Amravati, Maharashtra, India. OBJECTIVE To know magnitude of abortion complications, care sought by rural tribal women. RESULTS In Sewagram villages 3.30\%, in Melghat $0.32 \%$ reported complications with spontaneous abortions (SA) and $1 \%$ in Sewagram villages, $0.1 \%$ in Melghat with induced abortions (IA). In Sewagram villages of 24 (4.3\%) who had complications of SA, $33.3 \%$ each (1.4\% of SA)reported vaginal bleeding, abdominal pain, weakness $29.16 \%(1.2 \% \mathrm{SA})$, backache\%(0.7\% of $\mathrm{SA})$,fever $12.5 \%(0.5 \%$ of SA), vaginal discharge $8.33 \%$ ( $0.3 \%$ of SA), other complications $8.33 \%$ ( $0.36 \%$ of SA). Of 7 (3.9\% of all 177), who had complications after IA, $57.1 \%$ (2.2\% of all IA) reportedvaginal bleeding, $28.5 \%$ (1.1\% of IA) abdominal pain. In Melghat 4 reported complications after SA $(0.32 \%$ SA), $2(0.16 \%$ SA), abdominal pain, one (0.08\% SA) vaginal bleeding, one ( $0.08 \%$ of SA) backache.In Melghat of 2 women (3.7\%) out of 27 IA cases who had complications. one had vaginal bleeding, discharge, pain,weakness, other vaginal bleeding. In Melghat2 of total 6 sought health facility care, no specialists in spite of complications. There was neither abortion related mortality nor near miss morbidity, severe morbidity. CONCLUSION Research is needed about traditional therapies, reverse pharmacology, socio behavioral issues in addition to creating awareness of abortion complications, long term sequlae, necessity of care seeking.
\end{abstract}

\section{Background}

Abortion, be it spontaneous or induced is most common adverse outcome of pregnancy. Abortions may be associated with complications that constitute public health challenges globally, more so in developing countries. Also in many countries, induced abortions are still unauthorized because of abortion laws of countries. So unsafe abortions continue to occur and kill women globally ${ }^{1}$. In regions where abortion is permitted, utility of health facilities varies because of various reasons which include lack of awareness and /or resources, secrecy and beliefs in many countries. And also some complications like bleeding are inherent with abortions, be it SA or IA. Complications can occur in any case, anywhere, at safe health facilities too. So abortions affect women's health globally. Singh reported that millions of women in the world suffered due to non- availability or nonuse of treatment for abortion complications ${ }^{2}$. Deaths resulting from abortions are preventable, yet they continue to occur because unsafe practices go on, specially because abortion is a personal and private aspect of a woman's life ${ }^{3}$. Country's laws, policies and programs affect availability, utility of abortion services and effects. Not much is known about the status of all such aspects in rural tribal women who either do not have services for abortion complications or do not have access or do not use suchservices. 


\section{Objective}

To collect community-based information about complications of SA and IA and care sought by rural tribal women living with extremepoverty in villages of two districts of Maharashtra, in India.

\section{Methodology:}

After approval of ethics committee of the institute community based study was carried out in villages of two districts of Maharashtra of India, 65 in Dharni Block of Melghat in Amravati District and 53 villages near Sewagram of Wardha District, making a total of 118 villages, with a population of around one lac ten thousand. Study subjects, women of 15-44 years from every fourthhouse, were interviewed by the research assistants. Those who had complications in relation to SA or IA were the study subjects. Informed consent for recording information on a hard tool was taken before administering the predesigned and pretested questionnaire in local language by one to one, face to face direct interviews. Responses were recorded then and there on the questionnaire. No one was given questionnaire to fill. Focus group discussions (FGDs) were also conducted in the same villages with no age or abortion criteria. All those women of villages who were willing to participate in FGDs were part of the FGDs, 8-10 in a group in anyvillage.

\section{Results}

Of the 549 women who had SA abortionsin villages near in Sewagram in Wardha district, 24 (4.3\%) said they had complications. Four $(16.6 \%)$ of 24 with complications afterSAhad pregnancy of 69 weeks, 10 (41.6\%) 10-13 weeks, 5 (21\%) of 14-17 weeks and 5 (21\%) had pregnancy of 18-20 weeks. Of the 24 women who had complications, $33.3 \%$ (1.4\% of all SA) reported vaginal bleeding, $33.3 \%$ (1.4\% ofSA)abdominalpain, $8.33 \%$ (0.3\% ofSA)vaginaldischarge, $12.5 \%$ (0.5\% of SA)fever, $29.16 \%$ (1.2\% of SA) weakness, $16.6 \%$ ( $0.7 \%$ of SA) backache and $8.33 \%$ ( $0.36 \%$ of SA) other complications. Of the 24 women, $16(66.7 \%)$ sought services from Private hospitals, 3 (12.5\%) from Medical colleges, $2(8 \%)$ from Subcenters. Overall twenty-one (87.5\%) women were managed at health facilities. Three (12.5\%) women remained at home and family members gave home remedies even for complications of abortions. Of the total 177 cases of IA in villages of Sewagram region, $7(3.9 \%)$ said they had complications after IA, three $(42.82 \%$ of 7$)$ had IA of 6- 9 weeks pregnancy, 2 (28.57\%) of 10-13 weeks, one (14.28\%) of 14-17 weeks and one (14.28\%) of $18-20$ weeks. All 7 women received medical therapy. Six of 7 women with complications sought care from private hospitals (85.75\%) and one from public healthfacility. In Melghat region, of 1217 women who had SA, only $4(0.32 \%)$ said they had complications, one each had abortion of 6-9 weeks, 10-13 weeks, 1417 weeks and 18-20 weeks pregnancy. Of these 4 women, one $(0.08 \%$ of SA) had vaginal bleeding, $2(0.16$ $\%$ of SA) abdominal pain and one woman reported backache (0.08\% of SA). All 4 women had aborted at home and were managed by family members at home even for complications. No treatment was sought from any health facility. When asked about reasons for not using health facility even for complications, one said there were no resources, one had transport problem and $2(50 \%)$ had their own beliefs for not seeking care from any health facility. Three women (75\%) had home remedies and one sought help of local nurse midwife for additional medication at home. In Melghat region of the 27 women who had IA, 2 (7.4\%) said they had complications, one each had IA of 10-13 weeks and 18-20 weeks pregnancy. Many did not report of any complications, more so in Melghat region. During FGDs it was revealed that women lacked awareness about possible complications of abortions. They had their own beliefs too. There was ignorance about abortion complications more so in Melghat region where there was more poverty, illiteracy, access problems, lack of infrastructure and scarce health facilities. There was no abortion related maternal death, no near miss, not even severe illness in these villages over the years for which abortion complications information was sought.(Tables 1,2,3, and 4). 


\section{Discussion}

Early and late complications do occur with or after SA or IA, either because abortions are managed by untrained persons or at unsafe places or by unsafe modes or because of inherent problems like bleeding in relation to abortion which can occur anytime, irrespective of person performing or place of abortion. Even a woman with SA can have heavy bleeding, long termsequlaeand recurrence too. Complications also depended on the duration ofpregnancy which got aborted. The concept of post/peri abortion care (PAC) has evolved in the recent past. It is a global approach towards reducing the maternal mortality and morbidity due to complications of SA and IA with various medical and social interventions to ensure improvements in women's sexual and reproductive health ${ }^{4}$. The essential elements of PAC include emergency treatment of incomplete abortion, bleeding, infection, fever, pain as well as contraceptive counseling with desired services and linkage to other emergency services. However, the mortality and morbidity risks associated with safe or unsafe IA not only depended on the availability and quality of abortion care, but also on woman's beliefs, willingness and ability to seek services. Ganatra et al ${ }^{5}$ reported that around 25 million unsafe abortions (45\% of all abortions) occurred between 2010 and 2014 every year worldwide. The majority of unsafe abortions (97\%), were in developing countries (Africa, Asia and Latin America). WHO also reported that 19 of every 20 unsafe abortions took place in less developed regions of the world ${ }^{6}$ and this was where $98 \%$ of abortion-related deaths occurred ${ }^{7}$.So women's perceptions, beliefs and health seeking matter a lot. Estimated 6.8 million abortions occurred every year in South Central Asia, at a rate of 17 unsafe abortions per 1000 women $^{\mathbf{8}}$. Systematic analysis of 417 data sets from 115 countries estimated the prevalence of maternal deaths from abortive outcomes (ectopic pregnancy inclusive) as $8 \%$. Overall, sub-SaharanAfrican countries had the highest contribution to maternal deaths due toabortive outcomes ${ }^{\mathbf{9}}$. Haddad et al ${ }^{\mathbf{1 0}}$ also reported that worldwide 47000 women died due to complications of unsafe abortions, representing $13 \%$ of pregnancy related deaths. Review of various studies by Johnston ${ }^{\mathbf{1 1}}$ revealed that nearly $18 \%$ of all maternal deaths in India, were abortion related. Present community based study of magnitude of SA or IA, related complications, care sought by rural tribal women of two Districts of Maharashtra, India, was carried out to know the community based burdeon of abortion complications. There were access problems, lack of resources, lack of awareness, scarce health services, and also quite a few things were not obvious in Dharni Block of Melghat, hilly forestry region with extreme poverty. However overall $3.3 \%$ women reported complications in relation to SA in Sewagram region and0.3\% women of Dharni Block,10 times less. In Sewagram region care providers were family members, medical officers, specialists, traditional birth attendants and ASHAs in $62 \%, 25 \%, 12 \%, 2 \%$ and $1 \%$ respectively. Overall $12.5 \%$ of the 24 women who had complications were managed at home and $66.7 \%, 12.5 \%$ and $8.34 \%$ were managed at Private hospitals, Medical colleges and District hospital respectively. Care seeking seemed to be related to awareness, resources, access to available facilities and beliefs also. Family members were care providers for those who remained at home and the rest $22.5 \%$ were managed by medical officers and only $3.75 \%$ by specialists at health facilities. Abortion is usually kept secret and so private servicesaresoughtmoreoften.Inthesevillagestribalwomensoughtprivate services even with extreme poverty. It is essential for policy makers to know this aspect of abortion care. In a study, at least $9 \%$ of abortion-related hospital admissions had a near-miss event and around $1.5 \%$ ended in death ${ }^{\mathbf{1 0}}$. Hemorrhage was the most common complication reported. The pooled percentage of abortion- related hospital admissions with severe hemorrhage was $23 \%$, with around $9 \%$ having near-miss morbidity due to hemorrhage. Results suggested that a substantial percentage of abortion related hospital admissions had potentially life-threatening complications. Present study revealed that in rural community, $1 \%$ women reported complications with IA in the form of heavy vaginal bleeding and pain in abdomen in Sewagram region and $0.16 \%$ in Melghat region. Not very high numbers. These eventful IA in Sewagram region were cases performed at private hospitals, either for spacing $(29 \%)$ or for health reasons $(71 \%)$ and were conducted by medical means in $71 \%$, and surgical procedures in $28 \%$. Whatever was easily available was used was obvious. However there were no major problems reported. No one seemed to have complications to cause near miss or even severe illness. There was no abortion related death in these villages during the whole duration. A lot of research is needed about practices, specially because there were no major complications. Further more women with pregnancy of 10-13 weeks had complications. It is a grey zone. 
At this gestation medical methods are not used and surgical procedures are likely to cause trauma. It is known that second trimesterIAcarriedahigherriskofcomplicationsbuttheycontinuedinthisregion. However dangerous complications did not occur even in these women. With FGDs it was obvious that there was lack of awareness about possible complications. In a study it was found that in seven of ten countries, less than $10 \%$ of primary level facilities could provide basic PAC, and in eight of ten countries less than $40 \%$ of referral-level facilities could provide comprehensive $\mathrm{PAC}^{\mathbf{1 2}}$. In the present analysis, not many complications were reported and no services were sought by many even for complications. Primary Health centre, subcentre did not provide PAC. In a study $7.9 \%$ women experienced complications ${ }^{\mathbf{1 3}}$. Case fatality rate was worst for abortion-related infections (19.1\%). In the present study most common post-abortion complications reported were excessive vaginal bleeding and lower abdominal pain but neither in many women,nor heavy. They did not lead to severe illness or near miss morbidity. Other less frequent complications were high grade fever, foul smelling discharge, backache and weakness, probably infection related but still did not lead to severe illness. A community-based study in Madhya Pradesh, revealed that more than one out of two IA among rural women (57\%) and more than two of five IA among urban women (46\%) resulted in at least one complication ${ }^{\mathbf{1 4}}$. It was not found in the present study which was community based in villages with extreme poverty. Whatever information was possible verbally was collected and analyzed. There were no records. Because of linkage with maternal services information about severe illness, near miss cases, maternal deaths due to any reason was available. So it was obvious that in this region there were not many problems in abortion cases. Doorman et $\mathrm{al}^{\mathbf{1 5}}$ reported thatindigenous people and local communities (IPLCs) knowledge and practices rely on holistic and integrative conceptualizations of nature and value systems acknowledging interlinked human-nature relations. IPLCs hold a body of knowledge that has been accumulated through generations within their specific cultural and environment context. Using knowledge systems as equal partners informing one another requires bridging them, rather than synthesizing them. Knowledge co- production as a dialog and partnership can harness the practical wisdom and cultural values of IPLCs towards innovative solutions. Conclusion Awareness is needed about abortion complications. Also a lotof research is needed about traditional medicine, reverse pharmacology and sociobehavioural aspects too.

\section{ACKNOWLEDGEMENT}

We are grateful to the Indian Council of Medical Research (ICMR), New Delhi for the financial support for doing the study. We thank the Director General ICMR, and also everyone in the division of Reproductive Biology and Maternal Health Child Health, ICMR New Delhi, specially Ex Chief, Dr. Malbika Roy, Dr. R. S. Sharma and Dr. Shalini Singh for all the help and support. We are also grateful to Dr. R. B. Shrivastav and others at ICMR headquarters. We thank the rural tribal women for the cooperation in conducting the study. I am myself grateful to my colleagues Dr. Suchi Jain, Dr. Naina Kumar, Dr. Ketki for all the help. Thanks also to all the research assistants office staff for the information collected and help in analysis of the data and documentation.Disclosure of InterestsThere were no conflicts of interests, financial, personal, political, intellectual or religious.Contribution to Authorship:Prof. S. Chhabra conceived of the presented idea, contributed to the design and implementation of the research, to the analysis of the results and to the writing of the manuscript. Dr. Suman A. contributed to the final analysis and documentation of the results.Details of Ethics ApprovalStudy was carried out after approval of ethics committee of the Institutional Ethics Committee For Research on Human Subjects Ref. No. MGIMS/IEC/ONGY/42/2013FundingFunding was provided by Indian Council of Medical Research, New Delhi, India. 


\section{References:}

1. Fawcus SR. Maternal mortality and unsafe abortion. Best practice \& research Clinical obstetrics\&gynaecology. 2008; 22(3):533-48.

2. Singh S, Maddow-Zimet I. Facility-based treatment for medical complications resulting from unsafe pregnancy termination in the developing world, 2012: a review of evidence from 26 countries. BJOG: An International Journal of Obstetrics \&Gynaecology. 2015 Aug; 123(9):1489-98.

3. Grimes DA, Benson J, Singh S, Romero M, Ganatra B, Okonofua FE, Shah IH. Unsafe abortion: the preventable pandemic. The lancet. 2006 Nov 25;368(9550):1908-19.

4. Evens E, Otieno-Masaba R, Eichleay M, McCARRAHER DO, Hainsworth G, Lane C, Makumi M, Onduso P. Post-abortion care services for youth and adult clients in Kenya: a comparison of services, client satisfaction and provider attitudes. Journal of biosocial science. 2014 Jan;46(1):1-5.

5. Ganatra B, Gerdts C, Rossier C, Johnson Jr BR, Tunçalp Ö, AssifiA, Sedgh G, Singh S, Bankole A, Popinchalk A, Bearak J. Global, regional, and subregional classification of abortions by safety, 2010-14: estimates from a Bayesian hierarchical model. The Lancet. 2017 Nov 25; 390(10110):2372-81.

6. Unsafe Abortion: A major public health problem. Safe motherhood. 2000; 28 (1): 4.

7. WHO Unsafe abortion. Global and regional estimates of incidence of unsafe abortion and associated mortality in 2008.6th edn. World Health Organization, Geneva2011 http://apps.who.int/iris/bitstream/10665/44529/1/9789241501118_eng.pdf(accessed Sept 19, 2017).

8. Shah I, Ahman E. Unsafe abortion in 2008: global and regional levels and trends. Reproductive health matters. 2010 Jan 1; 18(36):90-101.

9. Say L, Chou D, Gemmill A, Tunçalp Ö, Moller AB, Daniels J, Gülmezoglu AM, Temmerman M, Alkema L. Global causes of maternal death: a WHO systematic analysis. The Lancet Global Health. 2014 Jun $1 ; 2(6): \mathrm{e} 323-33$.

10. Haddad LB, Nour NM. Unsafe abortion: unnecessary maternal mortality. Reviews in obstetrics and gynecology. 2009;2(2):122.

11. Johnston HB. Abortion practice in India: a review of literature. Mumbai: Centre for Enquiry into Health and Allied Themes; 2004.

12. Henshaw RJ, Henderson MW, Luebrecht DE, Gallagher MP, Ahigian EE, Bergman BA, inventors; Crown Equipment Corp, assignee. Control handle for a materials handling vehicle. United States patent application US 29/060,045. 1999 Feb 9.

13. Maxwell KN, Cholst IN, Rosenwaks Z. The incidence of both serious and minor complications in young women undergoing oocyte donation. Fertility and sterility. 2008; 90(6):2165-71.

14. Duggal R, Ramachandran V. The abortion assessment project-India: key findings and recommendations. Reproductive health matters. 2004 Jan 1;12(sup24):122-9.

15. Doorman L, Reyes-Garcia V, Martin- Lopez B, Berkes F. Learning from Indigenous Populations and Local Communities. Learning from Indigenous populations and local communities, one earth (2019), https://doi.org/10.1016/j.oneear.2019.07.002.

\section{TABLE- 1}

\section{SPONTANEOUS ABORTION RELATED COMPLICATIONS IN SEVAGRAM REGION}




\begin{tabular}{|c|c|c|c|c|c|c|c|c|c|}
\hline Total & Total & Total & Total & Total & Total & Total & Total & Total & Total \\
\hline Cases- & Cases- & Cases- & Cases- & Cases- & Cases- & Cases- & Cases- & Cases- & Cases- \\
\hline 24 In & 24 In & 24 In & 24 In & 24 In & 24 In & 24 In & 24 In & 24 In & 24 In \\
\hline 53 & 53 & 53 & 53 & 53 & 53 & 53 & 53 & 53 & 53 \\
\hline $\begin{array}{l}\text { Vil- } \\
\text { lages }\end{array}$ & $\begin{array}{l}\text { Vil- } \\
\text { lages }\end{array}$ & $\begin{array}{l}\text { Vil- } \\
\text { lages }\end{array}$ & $\begin{array}{l}\text { Vil- } \\
\text { lages }\end{array}$ & $\begin{array}{l}\text { Vil- } \\
\text { lages }\end{array}$ & $\begin{array}{l}\text { Vil- } \\
\text { lages }\end{array}$ & $\begin{array}{l}\text { Vil- } \\
\text { lages }\end{array}$ & $\begin{array}{l}\text { Vil- } \\
\text { lages }\end{array}$ & $\begin{array}{l}\text { Vil- } \\
\text { lages }\end{array}$ & $\begin{array}{l}\text { Vil- } \\
\text { lages }\end{array}$ \\
\hline $\begin{array}{l}\text { Duration } \\
\text { of Preg- } \\
\text { nancy }\end{array}$ & {$[?] 6 \mathrm{wks}$} & $\begin{array}{l}{[?] 6-} \\
{[?] 9 \mathrm{wks}}\end{array}$ & $\begin{array}{l}{[?] 10-} \\
{[?] 13 \mathrm{wks}}\end{array}$ & $\begin{array}{l}{[?] 14-} \\
{[?] 17 \mathrm{wks}}\end{array}$ & $\begin{array}{l}{[?] 18-} \\
{[?] 20 \mathrm{wks}}\end{array}$ & $\begin{array}{l}{[?] 18-} \\
{[?] 20 \mathrm{wks}}\end{array}$ & Total & Total & Total \\
\hline No. & - & 4 & $10^{*}$ & 5 & 5 & 5 & 24 & 24 & 24 \\
\hline$\%$ & - & 16.67 & 41.67 & 20.84 & 20.84 & 20.84 & 100 & 100 & 100 \\
\hline Place of & Quack & Sub- & District & Private & Medical & Medical & Home & Total & Total \\
\hline Treatment & & $\begin{array}{l}\text { centre/P } \\
\mathrm{H} \mathrm{C}\end{array}$ & Hospital & Hospital & College & College & & & \\
\hline No. & - & 2 & 0 & $16^{*}$ & 3 & 3 & 3 & 24 & 24 \\
\hline$\%$ & & 8.34 & 0 & 66.67 & 12.5 & 12.5 & 12.5 & 100 & 100 \\
\hline $\begin{array}{l}\text { Person } \\
\text { managing }\end{array}$ & Skilled & $\begin{array}{l}\text { Untrained/ } \\
\text { Dai }\end{array}$ & Total & Total & Total & Total & Total & Total & Total \\
\hline No. & $24^{*}$ & - & 24 & 24 & 24 & 24 & 24 & 24 & 24 \\
\hline$\%$ & 100 & - & 100 & 100 & 100 & 100 & 100 & 100 & 100 \\
\hline \multicolumn{2}{|c|}{$\begin{array}{l}\text { ManagementMedical } \\
\text { Mode }\end{array}$} & $\begin{array}{l}\text { Evacuati } \\
\text { on }\end{array}$ & $\begin{array}{l}\text { Home } \\
\text { based }\end{array}$ & Total & Total & Total & Total & Total & Total \\
\hline No. & $11^{*}$ & 10 & 3 & 24 & 24 & 24 & 24 & 24 & 24 \\
\hline$\%$ & 45 & 41.7 & 12.5 & 100 & 100 & 100 & 100 & 100 & 100 \\
\hline $\begin{array}{l}\text { Post- } \\
\text { abortion } \\
\text { complication }\end{array}$ & $\begin{array}{l}\text { Vaginal } \\
\text { bleeding } \\
\text { ns }\end{array}$ & $\begin{array}{l}\text { Vaginal } \\
\text { Discharge }\end{array}$ & $\begin{array}{l}\text { Abd. } \\
\text { Pain }\end{array}$ & Distention & Fever & Weakness & Weakness & Urinary & $\begin{array}{l}\text { Backac } \\
\text { h e }\end{array}$ \\
\hline Number & $8^{*}$ & 2 & $8^{*}$ & 0 & 3 & 7 & 7 & & 4 \\
\hline$\%$ & 33.34 & 8.33 & 33.34 & 0 & 12.5 & 29.16 & 29.16 & & 16.66 \\
\hline \multirow{2}{*}{$\begin{array}{l}\text { Post- } \\
\text { abortion } \\
\text { care }\end{array}$} & Medical & Traditional & Others & None & Total & Total & Total & Total & Total \\
\hline & $23^{*}$ & - & 1 & - & 24 & 24 & 24 & 24 & 24 \\
\hline
\end{tabular}

TABLE - 2INDUCED ABORTION RELATED COMPLICATIONS IN VILLAGES OF SEWAGRAM REGION

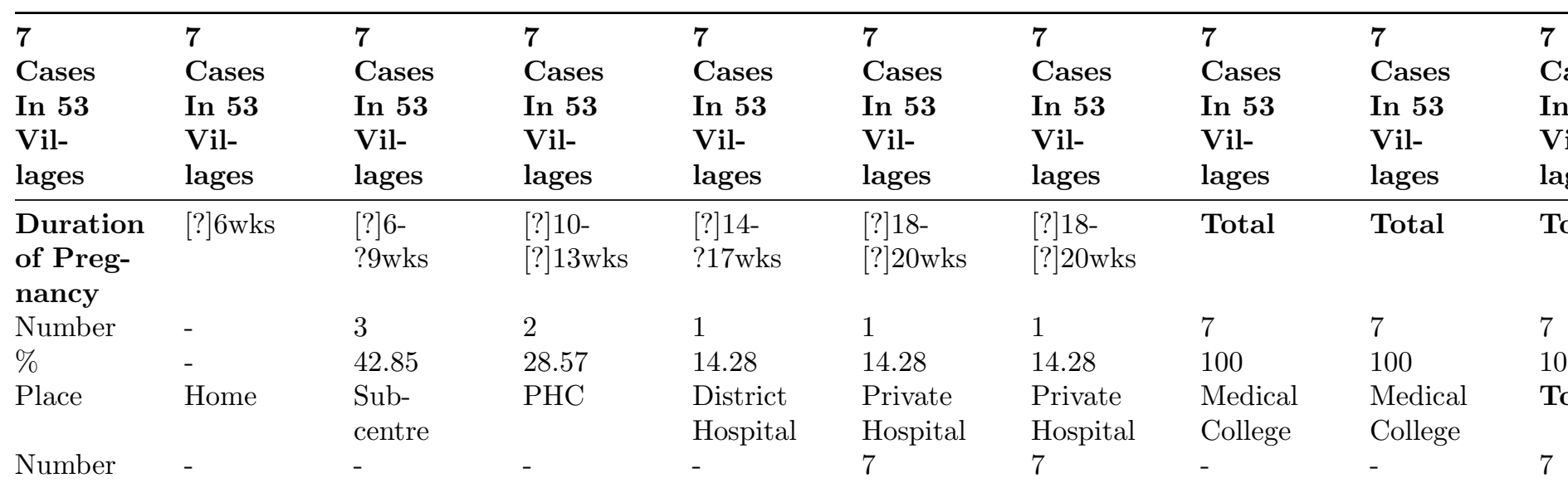




\begin{tabular}{|c|c|c|c|c|c|c|c|c|c|}
\hline $\begin{array}{l}7 \\
\text { Cases }\end{array}$ & $\begin{array}{l}7 \\
\text { Cases }\end{array}$ & $\begin{array}{l}7 \\
\text { Cases }\end{array}$ & $\begin{array}{l}7 \\
\text { Cases }\end{array}$ & $\begin{array}{l}7 \\
\text { Cases }\end{array}$ & $\begin{array}{l}7 \\
\text { Cases }\end{array}$ & $\begin{array}{l}7 \\
\text { Cases }\end{array}$ & $\begin{array}{l}7 \\
\text { Cases }\end{array}$ & $\begin{array}{l}7 \\
\text { Cases }\end{array}$ & 7 \\
\hline $\begin{array}{l}\text { Cases } \\
\text { In } 53\end{array}$ & $\begin{array}{l}\text { Cases } \\
\text { In } 53\end{array}$ & $\begin{array}{l}\text { Cases } \\
\text { In } 53\end{array}$ & $\begin{array}{l}\text { Cases } \\
\text { In } 53\end{array}$ & $\begin{array}{l}\text { Cases } \\
\text { In } 53\end{array}$ & $\begin{array}{l}\text { Cases } \\
\text { In } 53\end{array}$ & $\begin{array}{l}\text { Cases } \\
\text { In } 53\end{array}$ & $\begin{array}{l}\text { Cases } \\
\text { In } 53\end{array}$ & $\begin{array}{l}\text { Cases } \\
\text { In } 53\end{array}$ & In \\
\hline Vil- & Vil- & Vil- & Vil- & Vil- & Vil- & Vil- & Vil- & Vil- & $\mathrm{Vi}$ \\
\hline lages & lages & lages & lages & lages & lages & lages & lages & lages & la \\
\hline$\%$ & - & - & - & - & 100 & 100 & - & - & 10 \\
\hline Care & Self & Dai & ANM/ASHA & Doctor & Specialist & Specialist & Total & Total & Tc \\
\hline Provider & induced & & & & & & & & \\
\hline Number & - & - & - & 5 & 2 & 2 & 7 & 7 & 7 \\
\hline$\%$ & - & - & - & 71.42 & 28.57 & 28.57 & 100 & 100 & 10 \\
\hline Abortion & Private & Public & Home & Other & Total & Total & Total & Total & To \\
\hline Provider & Hospital & health & & & & & & & \\
\hline Number & 6 & - & - & 1 & 7 & 7 & 7 & 7 & 7 \\
\hline$\%$ & 85.75 & - & - & 14.25 & 100 & 100 & 100 & 100 & 10 \\
\hline $\begin{array}{l}\text { Person } \\
\text { conducting }\end{array}$ & $\begin{array}{l}\text { Doctor / } \\
\mathrm{HP}\end{array}$ & Nurse & $\begin{array}{l}\text { Untrained } \\
\text { Dai }\end{array}$ & Total & Total & Total & Total & Total & То \\
\hline Number & 7 & - & - & 7 & 7 & 7 & 7 & 7 & 7 \\
\hline$\%$ & 100 & - & - & 100 & 100 & 100 & 100 & 100 & 10 \\
\hline Method & Medical & Surgical & Folk / Self & Total & Total & Total & Total & Total & To \\
\hline Number & 5 & 2 & - & 7 & 7 & 7 & 7 & 7 & 7 \\
\hline$\%$ & 71.4 & 28.5 & - & 100 & 100 & 100 & 100 & 100 & 10 \\
\hline Care & Medical & Surgical & Traditional & None & Total & Total & Total & Total & Tc \\
\hline \multicolumn{10}{|l|}{ Provider } \\
\hline Number & 7 & - & - & - & 7 & 7 & 7 & 7 & 7 \\
\hline$\%$ & 100 & - & - & - & 100 & 100 & 100 & 100 & 10 \\
\hline \multicolumn{2}{|c|}{$\begin{array}{r}\text { Complications/aginal } \\
\text { bleeding }\end{array}$} & $\begin{array}{l}\text { Vaginal } \\
\text { Discharge }\end{array}$ & Abd. Pain & $\begin{array}{l}\text { Distenti } \\
\text { on }\end{array}$ & Fever & Weaknes s & $\begin{array}{l}\text { Urina } \\
\text { ry }\end{array}$ & Backache & 0 \\
\hline Number & 4 & - & 2 & - & - & - & - & - & - \\
\hline$\%$ & 57.14 & - & 28.57 & - & - & - & - & - & - \\
\hline
\end{tabular}

TABLE 3SPONTANEOUS ABORTION RELATED COMPLICATIONS COMPLICATIONS IN VILLAGES OF DHARNI, MELGHAT REGION

\begin{tabular}{|c|c|c|c|c|c|c|c|c|c|}
\hline $\begin{array}{l}\text { One } \\
\text { In } 65 \\
\text { Vil- } \\
\text { lages }\end{array}$ & $\begin{array}{l}\text { One } \\
\text { In } 65 \\
\text { Vil- } \\
\text { lages }\end{array}$ & $\begin{array}{l}\text { One } \\
\text { In } 65 \\
\text { Vil- } \\
\text { lages }\end{array}$ & $\begin{array}{l}\text { One } \\
\text { In } 65 \\
\text { Vil- } \\
\text { lages }\end{array}$ & $\begin{array}{l}\text { One } \\
\text { In } 65 \\
\text { Vil- } \\
\text { lages }\end{array}$ & $\begin{array}{l}\text { One } \\
\text { In } 65 \\
\text { Vil- } \\
\text { lages }\end{array}$ & $\begin{array}{l}\text { One } \\
\text { In } 65 \\
\text { Vil- } \\
\text { lages }\end{array}$ & $\begin{array}{l}\text { One } \\
\text { In } 65 \\
\text { Vil- } \\
\text { lages }\end{array}$ & $\begin{array}{l}\text { One } \\
\text { In } 65 \\
\text { Vil- } \\
\text { lages }\end{array}$ & $\begin{array}{l}\text { One } \\
\text { In } 65 \\
\text { Vil- } \\
\text { lages }\end{array}$ \\
\hline $\begin{array}{l}\text { Duration } \\
\text { of Preg- } \\
\text { nancy }\end{array}$ & [?]6wks & $\begin{array}{l}{[?] 6-} \\
{[?] 9 \mathrm{wks}}\end{array}$ & $\begin{array}{l}{[?] 10-} \\
? 13 \mathrm{w} \mathrm{ks}\end{array}$ & $\begin{array}{l}{[?] 14-} \\
? 17 \mathrm{wks}\end{array}$ & $\begin{array}{l}\text { [?]18- } \\
\text { ?20wk s }\end{array}$ & Total & Total & Total & Total \\
\hline Number & - & 1 & 1 & 1 & 1 & 4 & 4 & 4 & 4 \\
\hline$\%$ & - & 25 & 25 & 25 & 25 & 100 & 100 & 100 & 100 \\
\hline $\begin{array}{l}\text { Place of } \\
\text { 1stTreatmen }\end{array}$ & $\begin{array}{l}\text { Quack } \\
\text { nt }\end{array}$ & $\begin{array}{l}\text { Sub- } \\
\text { centre/PI }\end{array}$ & $\begin{array}{l}\text { Distric t } \\
\mathrm{H} \text {. }\end{array}$ & $\begin{array}{l}\text { Privat e } \\
\text { H. }\end{array}$ & $\begin{array}{l}\text { Medical } \\
\text { College }\end{array}$ & Home & Home & Total & Total \\
\hline Number & - & - & - & - & - & 4 & 4 & 4 & 4 \\
\hline$\%$ & - & - & - & - & - & 100 & 100 & 100 & 100 \\
\hline $\begin{array}{l}\text { Care } \\
\text { Provider }\end{array}$ & Family & Dai & $\begin{array}{l}\text { ANM/ } \\
\text { ASHA }\end{array}$ & Doctor & Specialist & Total & Total & Total & Total \\
\hline Number & 4 & - & - & - & - & 4 & 4 & 4 & 4 \\
\hline$\%$ & 100 & - & - & - & - & 100 & 100 & 100 & 100 \\
\hline
\end{tabular}




\begin{tabular}{|c|c|c|c|c|c|c|c|c|c|}
\hline $\begin{array}{l}\text { One } \\
\text { In } 65 \\
\text { Vil- } \\
\text { lages }\end{array}$ & $\begin{array}{l}\text { One } \\
\text { In } 65 \\
\text { Vil- } \\
\text { lages }\end{array}$ & $\begin{array}{l}\text { One } \\
\text { In } 65 \\
\text { Vil- } \\
\text { lages }\end{array}$ & $\begin{array}{l}\text { One } \\
\text { In } 65 \\
\text { Vil- } \\
\text { lages }\end{array}$ & $\begin{array}{l}\text { One } \\
\text { In } 65 \\
\text { Vil- } \\
\text { lages }\end{array}$ & $\begin{array}{l}\text { One } \\
\text { In } 65 \\
\text { Vil- } \\
\text { lages }\end{array}$ & $\begin{array}{l}\text { One } \\
\text { In } 65 \\
\text { Vil- } \\
\text { lages } \\
\end{array}$ & $\begin{array}{l}\text { One } \\
\text { In } 65 \\
\text { Vil- } \\
\text { lages }\end{array}$ & $\begin{array}{l}\text { One } \\
\text { In } 65 \\
\text { Vil- } \\
\text { lages } \\
\end{array}$ & $\begin{array}{l}\text { One } \\
\text { In } 65 \\
\text { Vil- } \\
\text { lages }\end{array}$ \\
\hline $\begin{array}{l}\text { Person } \\
\text { managing }\end{array}$ & Skilled & $\begin{array}{l}\text { Untrained/ } \\
\text { Dai }\end{array}$ & Other & & & Total & Total & Total & Total \\
\hline Number & 1 & - & 3 & - & - & 4 & 4 & 4 & 4 \\
\hline$\%$ & 25 & - & 75 & - & - & 100 & 100 & 100 & 100 \\
\hline Managemer & tMedical & $\begin{array}{l}\text { Evacuatio } \\
\mathrm{n}\end{array}$ & $\begin{array}{l}\text { Home } \\
\text { based }\end{array}$ & & & Total & Total & Total & Total \\
\hline Number & 1 & - & 3 & - & - & 4 & 4 & 4 & 4 \\
\hline$\%$ & 25 & - & 75 & & & 100 & 100 & 100 & 100 \\
\hline $\begin{array}{l}\text { Post- } \\
\text { abortion } \\
\text { care }\end{array}$ & Medical & $\begin{array}{l}\text { Traditiona } \\
1\end{array}$ & Others & None & None & Total & Total & Total & Total \\
\hline Number & 1 & - & 3 & - & - & 4 & 4 & 4 & 4 \\
\hline$\%$ & 25 & & 75 & & & 100 & 100 & 100 & 100 \\
\hline $\begin{array}{l}\text { Post- } \\
\text { abortion } \\
\text { complicatio }\end{array}$ & $\begin{array}{l}\text { Vagina l } \\
\text { bleedi } \\
\text { nng }\end{array}$ & $\begin{array}{l}\text { Vaginal } \\
\text { Discharge }\end{array}$ & $\begin{array}{l}\text { Abd. } \\
\text { Pain }\end{array}$ & $\begin{array}{l}\text { Distenti } \\
\text { on }\end{array}$ & Fever & $\begin{array}{l}\text { weak } \\
\text { ness }\end{array}$ & Urinary & Urinary & Backache \\
\hline Number & 1 & - & 2 & - & - & - & - & - & 1 \\
\hline$\%$ & 25 & - & 50 & - & - & - & - & - & 25 \\
\hline
\end{tabular}

TABLE 4INDUCED ABORTION RELATED COMPLICATIONS IN VILLAGES OF DHARNI MELGHAT

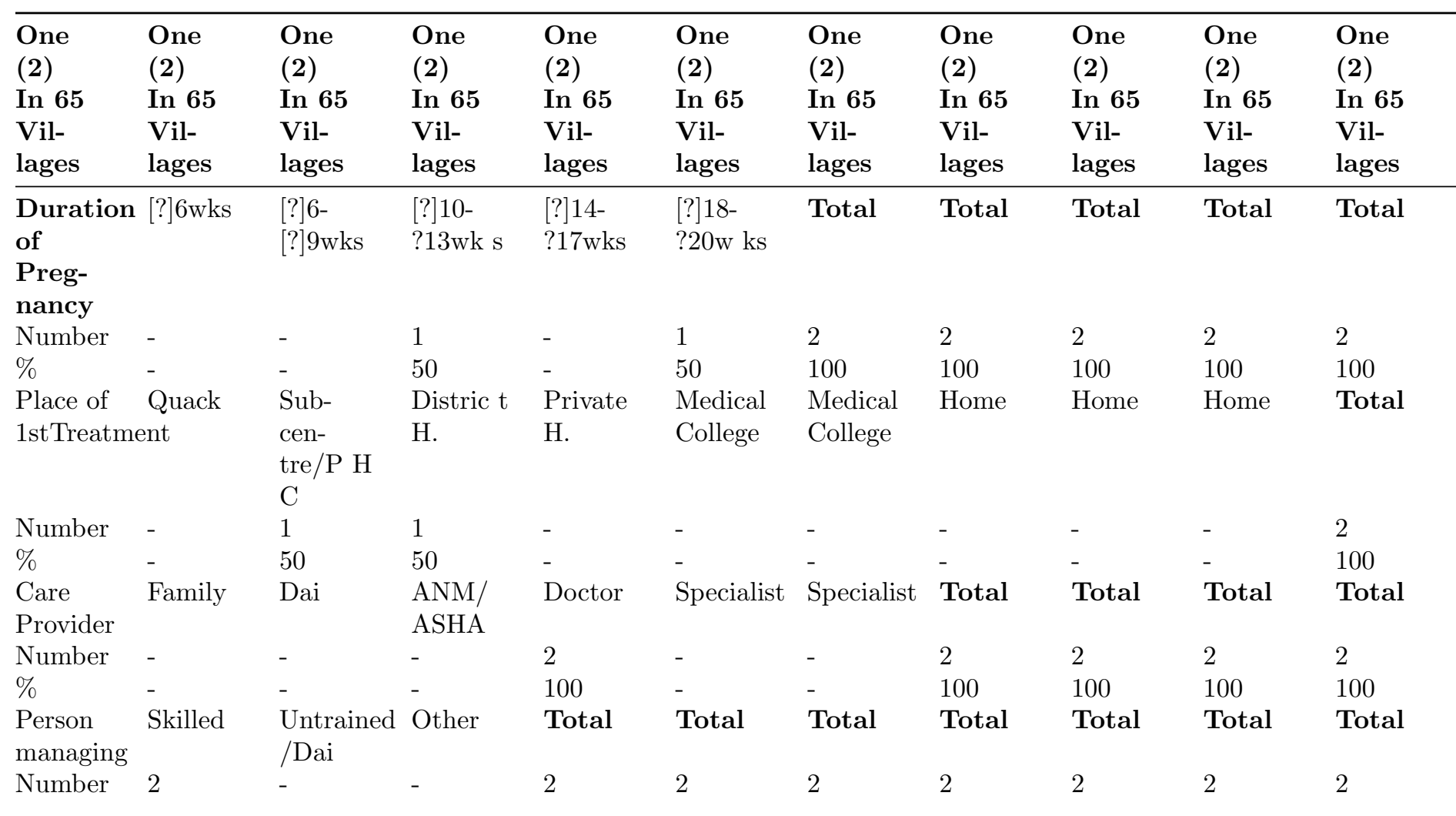




\begin{tabular}{|c|c|c|c|c|c|c|c|c|c|c|}
\hline $\begin{array}{l}\text { One } \\
(2) \\
\text { In } 65 \\
\text { Vil- } \\
\text { lages }\end{array}$ & $\begin{array}{l}\text { One } \\
(2) \\
\text { In } 65 \\
\text { Vil- } \\
\text { lages }\end{array}$ & $\begin{array}{l}\text { One } \\
(2) \\
\text { In } 65 \\
\text { Vil- } \\
\text { lages }\end{array}$ & $\begin{array}{l}\text { One } \\
(2) \\
\text { In } 65 \\
\text { Vil- } \\
\text { lages }\end{array}$ & $\begin{array}{l}\text { One } \\
(2) \\
\text { In } 65 \\
\text { Vil- } \\
\text { lages }\end{array}$ & $\begin{array}{l}\text { One } \\
(2) \\
\text { In } 65 \\
\text { Vil- } \\
\text { lages }\end{array}$ & $\begin{array}{l}\text { One } \\
(2) \\
\text { In } 65 \\
\text { Vil- } \\
\text { lages }\end{array}$ & $\begin{array}{l}\text { One } \\
(2) \\
\text { In } 65 \\
\text { Vil- } \\
\text { lages }\end{array}$ & $\begin{array}{l}\text { One } \\
(2) \\
\text { In } 65 \\
\text { Vil- } \\
\text { lages }\end{array}$ & $\begin{array}{l}\text { One } \\
(2) \\
\text { In } 65 \\
\text { Vil- } \\
\text { lages }\end{array}$ & $\begin{array}{l}\text { One } \\
(2) \\
\text { In } 65 \\
\text { Vil- } \\
\text { lages }\end{array}$ \\
\hline$\%$ & 100 & - & - & 100 & 100 & 100 & 100 & 100 & 100 & 100 \\
\hline Managem & nitledical & Evacuation & $\begin{array}{r}\text { n Home } \\
\text { based }\end{array}$ & Total & Total & Total & Total & Total & Total & Total \\
\hline Number & 2 & - & - & 2 & 2 & 2 & 2 & 2 & 2 & 2 \\
\hline$\%$ & 100 & - & - & 100 & 100 & 100 & 100 & 100 & 100 & 100 \\
\hline $\begin{array}{l}\text { Post- } \\
\text { abortion } \\
\text { care }\end{array}$ & Medical & Traditional & lOthers & None & Total & Total & Total & Total & Total & Total \\
\hline Number & 2 & - & - & - & 2 & 2 & 2 & 2 & 2 & 2 \\
\hline$\%$ & 100 & - & - & - & 100 & 100 & 100 & 100 & 100 & 100 \\
\hline $\begin{array}{l}\text { Post- } \\
\text { abortion } \\
\text { complicati }\end{array}$ & $\begin{array}{l}\text { Vaginal } \\
\text { Bleeding } \\
\text { on }\end{array}$ & $\begin{array}{l}\text { Vaginal } \\
\text { Discharge }\end{array}$ & $\begin{array}{l}\text { Abd } \\
\text { Pain }\end{array}$ & Distention & Fever & weakness & weakness & Urinary & Backache & Backache \\
\hline Number & 1 & 1 & 1 & - & 1 & 1 & 1 & 1 & 1 & 1 \\
\hline$\%$ & 50 & 50 & 50 & - & 50 & 50 & 50 & 50 & 50 & 50 \\
\hline
\end{tabular}

